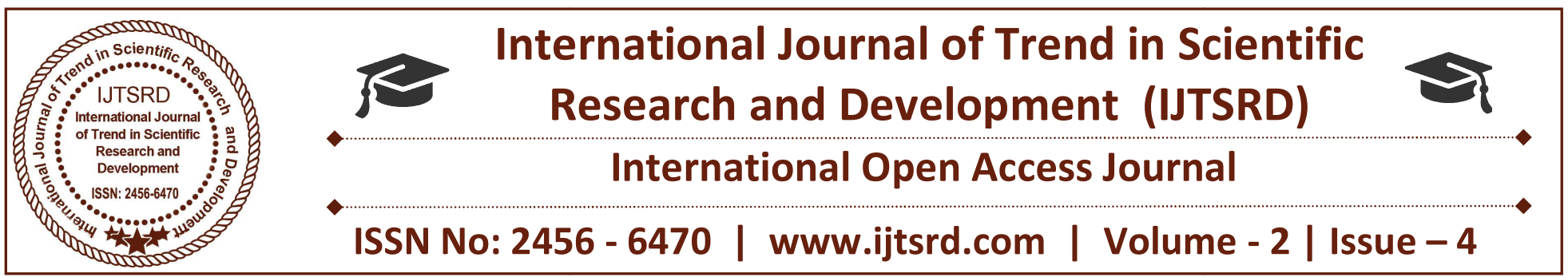

\title{
Role of Ethics in Modern Business Paradigm
}

\author{
Dr. Puja Mishra \\ Assistant Professor \\ Usha Martin University, Ranchi, Jharkhand, India
}

\begin{abstract}
Modern business has witnessed a number of changes. These changes are both negative as well as positive. As ethics in business relates to is the code of conduct, principles, practices and philosophies, it will guide the day to day business decisions considering its positive impact on society and its sustainability. The ethical principles and moral practices help the organisation in attaining what is best.
\end{abstract}

With the growing concern about climate change, food security and global health, the whole issue of business ethics has become a matter of widespread debate and consideration across the globe.

Thus this paper aims at bringing these diverse perspectives together in order to bring a comprehensive and holistic account of modern business ethics. This article also describes the ethical issues, which are vital to solving the problems related to business, and to give short preface to the moral issues drawn in the management of explicit problem areas in business.

Keywords: Ethics, Modern Business, Moral Issues

\section{INTRODUCTION}

Ethics is the discipline that examines one's moral standards or the moral standards of the society. It asks how these standards apply to our lives and whether these standards are reasonable or unreasonable, whether they are supported by good reasons or the poor ones. Therefore a person starts to follow ethics when he or she takes the moral standards absorbed from family, friends and institutions ethics is the study of moral standards whose explicit purpose is to determine as far as possible whether a given moral standard is more or less correct.

Business ethics is a specialized study of moral right or wrong. It concentrates on moral standards as they apply to business policies, institutions and behavior. It is a study of moral standards and how these apply to the systems of organisation through which modern societies produce and distribute goods and services, and to the people who work within these organizations. It not only includes moral norms and moral values, but also attempts to apply the conclusions of this analysis to that assortment of institutions, technologies, transaction activities and pursuits that we call business.

\section{ETHICS IN MODERN BUSINESS}

In today's world organizations are interested in building a strong relationship with its customers which is greatly related to its customers which is greatly related to the business policies adopted by the firms. Thus business ethics is of great importance in the modern business environment as customers pay a lot of attention to the public image of companies they are buying products or services from as well as the observation of ethical norms and principles by organizations and their leaders. Also, the unethical behavior is not acceptable in the modern business environment as it leads to the loss of a considerable part of customers, undermines the positive brand image or leads to the formation of a negative one and thus deteriorates consistently the marketing performance of modern organisations.

It is however observed that cases of violation of ethical business practices and unethical business 
policies still exist in the modern business environment. That is why many organisations are concerned with the elaboration of effective methods of prevention of the violation of business ethics and ethical principles. In this respect the development of code of ethics, code of conduct and the implementation of traditional fair completion principles can lead to the minimization of the risk of unethical behavior of the leaders. In this way, the prevention of unethical policies is required in the modern business environment as it maintains positive marketing practices and allows organizations to maintain their competitive position fairly, but the implementation of ethical business still confronts substantial difficulties, which can be eliminated by mutual efforts of organisation's, leaders, employees and customers as well as all stake holders involved in business that means that the establishment of ethical standard in business is essential

Business ethics is concerned with those issues not covered by the law or where there is no definite consensus on whether something is right or wrong. Discussions about the ethics of particular business practices may eventually lead to legislation once some kind of consensus is reached, but for most of the issues of interest to business ethics, the law typically does not currently provide us with guidance.

\section{CHARACTERISTICS OF BUSINESS ETHICS}

1. Business ethics is both science and art - business ethics is considered to be science because it presents the base for differentiating good from bad or fair from unfair actions. Whereas it is considered to be an art as it emphasizes practical use of behavioral sciences and principles.

2. Based on reality - business ethics is based on reality and social customs prevailing in the business environment. Thus business ethics is developed after testing the requirements of business environment, social customs and traditions and the rules of its conduct.

3. Has moral accountability - business ethics has the moral accountability to accept proper and improper things where it has not legal binding, the business accepts moral accountability only by its own will and not by any force.

4. Good intentions - the content of business ethics is good wishes, good opinion and expectations. It differentiates between good and bad, right and wrong actions of business
5. Guiding principles - it provide the guiding principles of business functions, it is the knowledge through which human behavior is learned in a business situation.

6. Universally accepted philosophy- business ethics is a universal philosophy, wherever there are business functions there it would become necessary to consider the questions relating to business ethics.

\section{IMPORTANCE OF ETHICS IN THE MODERN BUSINESS}

Today the importance of ethical business policies has increased even more because the globalization of the economy contributed to the consistent growth of competitions between the organizations, as a result organizations are growing more and more concerned with their positive public image, more over many companies spend a considerable part of their revenue on the formation of a positive brand image to attract new customers and to stimulate loyalty of existing customers. Ethics is the building block upon which our whole society is based, and business is a part of our society, and it is integral to the practice of being able to conduct business that follows a set of ethical standards.

Thus ethics in business policy is a set of honest standards but it is vital to understand that ethical standards established within an organisation should meet the general standards that are acceptable and applied in the society. Thus ethical business should incorporate values and standards established within the society's .organizations should show customers positive models of behavior and positive business pattern, which are ethically correct, customers in their turn naturally prefer companies that conduct ethical and responsible policies in relation to customers, environment, employees and other stakeholders.

\section{AREAS OF ETHICS IN MODERN BUSINESS MANAGEMENT}

The ethical issues faced by the managers in modern business can basically be divided into the given areas:

1. Employee relations - it relates to the way organization treats its employees

2. Customer's relations - it deals with how the organisation cares for, relates to and communicates with its customers.

3. Investor's relations - how the organisation relates to those that support it financially 
4. Vendor relations - the relationship an organization has with those who supply the products and services it needs

The business organisation handle these four areas in the same manner with a focus on being fair and honest to each of them respectively, however sometimes it may become difficult to be equally fair and honest to each of the four areas at the same time.

\section{NEED OF BUSINESS ETHICS}

Business operates within the society - it is a part of the subsystem of society. Business functionary must contribute to the welfare of the society in order to survive, develop and excel, business must earn social sanction of the society where it exists and functions, without earning social sanctions, business cannot get loyal customers, cannot operate in the marketplace. It will soon collapse and die away

Every business irrespective of size exists more on ethical means or in total regard to its social concern to survive long - otherwise, resorting to unethical behavior or not concerning to social welfare, it will call for its own doom. Thus business should be ethical and socially responsible.

Business needs to function as responsible corporate citizens in the country - it states that the organisations of the society which creates wealth for the country. Hence, narrow mentality and narrow goals and motives are to be avoided.

\section{EFFECT OF UNETHICAL BUSINESS PRACTICES}

Poor ethical decisions can affect an organisation in a number of ways such as

1. Legal troubles - business organizations that are unethical faces large fines and penalties.

2. Poor worker performance - lack of ethics within the organisation affects the way employees do their job. Employees behave unethically because they imitate their leaders who are also behaving unethically. This can ultimately damage the organization. The employees can even become discouraged to do work for the unethical organisation.

3. Reduced organisational credibility - when an organization is unethical it affects its reputation. Not only will the leaders and organization lose respect in front of their employees, they will even lose credibility amongst the general public. This may lead to reduced sales, lost customers and even major financial loss.

\section{References}

[1] G. Beijer Brain Drain, p. 1, Brill Archieve, 1972 ISBN 978-90-247-145-7

[2] Thomas L Friedman The World is Flat, p. 147, Macmillan, 2007 ISBN 978-0-374-29278-2

[3] Personal Administration,Koga/Cusha, 1973

[4] Human Resource Management, Mc Graw Hill, $6^{\text {th }}$ Ed. 2000

[5] Personal Management Mc Graw Hill, $6^{\text {th }}$ Ed., 1984

[6] Alan Greenspan The Age of Turbulence: Adventures in a New World, p. 405, The Penguin Press, 2007 ISBN 978-1-9420-131-8 